WORKING PAPER NO. 2

Sept 1994

\title{
The Role of International Research Agencies in Strengthening Forest Research in Africa
}

\author{
J.A. Sayer, F.S.P. Ng and J.R. Palmer
}

Summary

Among the range of problems requiring research, some are most relevant for particular countries and require special local knowledge or facilities for research. Others are common to eco-regions or ecosystems which span several countries; for these, a regional approach through networked research groups may be more efficient and effective. CIFOR has identified a set of strategic problems, through surveys of demands, which involve research leading to generalizable results, adaptable to local situations. CIFOR will work through institution-strengthening associations with national partners towards resolution of these strategic problems.

CENTER FOR INTERNATIONAL FORESTRY RESEARCH

office address: Jalan Gunung Batu 5 Bogor 16001 Indonesia

mailing address: P.O.Box 6596, JKPWB Jakarta 10065 Indonesia

tel.: +62(25 1) 34-3652 fax: +62(25 1) 32-6433

cmail: cifor@cgnet.com 


\section{The CGIAR System}

The Consultative Group on International Agricultural Research (CGIAR) is an informal association of 41 public and private sector donors that supports a network of sixteen international agricultural research centers, CIFOR being the newest of these centers. The Group was established in 1971. The CGIAR centers are part of a global agricultural research system which endeavor to apply international scientific capacity to solution of the problems of the world's disadvantaged people.

\section{CIFOR}

CIFOR was established under the CGIAR system in response to global concerns about the social, environmental and economic consequences of loss and degradation of forests. It operates through a series of highly decentralized partnerships with key institutions and/or individuals throughout the developing and industrialized worlds. The nature and duration of these partnerships are determined by the specific research problems being addressed. This research agenda is under constant review and is subject to change as the partners recognize new opportunities and problems. 


\title{
The Role of International Research Agencies in Strengthening Forest Research in Africa ${ }^{1}$
}

\author{
J. A. Sayer ${ }^{2}$, F. S. P. $\mathrm{Ng}^{3}$ and J. R. Palmer ${ }^{4}$
}

\begin{abstract}
Summary
Among the range of problems requiring research, some are most relevant for particular countries and require special local knowledge or facilities for research. Others are common to eco-regions or ecosystems which span several countries; for these, a regional approach through networked research groups may be more efficient and effective. CIFOR has identified a set of strategic problems, through surveys of demands, which involve research leading to generalizable results, adaptable to local situations. CIFOR will work through institution-strengthening associations with national partners towards resolution of these strategic problems.
\end{abstract}

\section{Introduction}

A distinction is often made between agriculture and forestry in the following way:

- in agriculture, the farmer modifies the environment to suit the crop;

- in contras, the forester develops management systems which largely accept the environment as it is. It is more economic and may be more sustainable to improve the productivity of the trees and forests which will survive and grow in the given environment, than to plough, fertilize and irrigate like a farmer. The often much longer production period for forests than for agricultural crops, and the associated compound interest costs of investments, account for different perspectives of farmer and forester.

This distinction then leads to the argument that forest management systems must be site- or species-specific and that it is dangerous to generalize. Hence, it is reasoned, every distinctive region needed its own research capability. This argument translates politically into every country seeking to develop a complete research system, with outposts in all major ecological and other kinds of regions. Research for production forestry on an industrial scale is usually treated as a function of government, because it is difficult for the private investor to capture all the benefits. So forestry research has tended to become a longterm government commitment.

Countries facing a need to reduce substantially the costs of maintaining the public sector, perhaps because of structural adjustment programmes, may seek to privatize forestry research. This could be an attractive option for research on short-rotation, intensively-cultivated plantation forests, or for research on processing of forest products, where the pay-back periods may be short and there are reasonable possibilities of patent protection. It is not really an option for research which is geared to non-industrial clients. These include the non-commercial domestic consumers of forest products as well as consumers and users of what are generally treated as public benefits: such as conserved biodiversity; perennial flows of clean water; protection from erosion and sedimentation, wind damage and fire, pests and pathogens; recreational potential; pollution absorption and carbon fixation. These kinds of

\footnotetext{
1 Invited paper for the IUFRO Subject Group S6.06-00 Symposium 'Management of Forest Research: Emerging Trends', IUFRO in association with CSIR, 5-6 September 1994, Cape Town, South Africa.

2 Director General, Center for International Forestry Research (CIFOR), P.O.Box 6596, JKPWB Jakarta 10065, Indonesia.

3 Director, Research Support and Information, Center for International Forestry Research (CIFOR), P.O.Box. 6596, JKPWB Jakarta 10065, Indonesia.

4 Tropical Forestry Services Ltd., Oxford OX2 7AY, U.K.
} 
research are not generally attractive to the private sector. Does this oblige governments to retain them as national obligations ?

This question has become more acute recently. Governments in many developing countries have been required by structural adjustment programmes to cut their institutional support much more severely than they had at first expected. At the same time, them has been rising recognition that a concentration of research which benefit primarily the industrial sector leaves large number of forest stakeholders without assistance from research. These stakeholders include artesanal and domestic processors of forest products, and the marketing and distribution chains associated with these processors. The stakeholders include also those who derive their livelihood at or near the forest margin, and whose activities determine largely whether, when and how much the forest is conserved, degraded or destroyed.

Compared with the beneficiaries of forestry research in the industrial sector, the potential nonindustrial beneficiaries are enormously greater in number. They also have far greater impact on the survival and health of the forest than does the industrial sector. There was a substantial shift in global forestry priorities around the time of the 8th World Forestry, Congress in 1978, and the following 17th IUFRO World Congress in 1981. Since then, national (government) forestry research organizations have tended to move away from industrial problems and to concentrate on the needs of the people at the forest margin. The degree of this shift varies from region to region, being strong in Africa but less prominent in Latin America.

\section{National forestry research systems}

We use the term "national forestry research systems" (NFRS) as the counterpart of "national agricultural research system". The terms indicate that research is not exclusive to institutes with national government mandates. In many countries, the bulk of forestry research is undertaken in universities and by non-government organizations (NGOs). This is especially true of research which incorporates non-biological or non-technological components, particularly research including social sciences and economics. Some government forestry research institutes (FRI) have regulations or staffing structures which make it extremely difficult for them to absorb recruits from non-biological disciplines. In a few developing countries, the private sector also undertakes significant research, usually on the processing side to develop products which will meet export-quality standards.

In a few cases, a professional forestry qualification is obligatory for admission to a governmentFRI. Such regulations impede the ability of FRIs to respond to the actual needs of forestry-affected people, as shown by numerous surveys such as sector studies associated with National Forestry Action Programmes. However, even when a FRI appears to bc remote from the major forestry problems of a ountry, there often exist mechanisms for informal collaboration between the FRI, universities, integrated conservation and development projects, and NGOs. Certainly in Latin America, it is not unusual for a government forestry research staff member to work voluntarily for a NGO at weekends and on holidays.

The previous comments are not intended to portray FRIs as obsolete or unresponsive dinosaurs. Rather, understanding of the range and type of demands on forests has developed more quickly than the speed with which most governments can react positively. For the foreseeable future, there will be no slackening of demand for research to support industrial production forestry and industrial processing of forest products. Certainly the nature of that research will change. It will, or should, build on the increase in the global knowledge base.

On the "growing" side of forestry, research in support of commercial production will need to keep up with the biological problems of growing and maintaining productive trees and forests on land which is usually marginal by agricultural standards. Research is increasingly required to bring back into production land which has been degraded by unsuitable farming systems; land which has substantially lost its top soil through erosion under poorly chosen or improperly cultivated crops; land which has become saline or sodic through inadequate management of irrigation systems; land silted by floods and with blocked drainage systems; land which was steep, rocky, sandy, too exposed, with too shallow soil to sustain prolonged arable cropping or grazing. However, ever-increasing pressure on land from expanded or displaced human populations requires many governments to try to rehabilitate such depleted lands and where possible to obtain industrially-useful products from them.

On the "processing" side of forestry, productivity gains through silviculture and tree improvement can easily be nullified by careless harvesting and inefficient manufacture. 
Techniques developed in Scandinavia for processing of small trees and recovery of residues need to be adapted and widely disseminated in most developing countries. It is tragic to see included in burning piles of sawmill residues many large pieces of defect-free timber which would command huge prices if incorporated into furniture and other finished products in Northern countries.

Penetration of export markets, and retention of market share, require processors to keep up with the increasingly stringent legislation on health and safety. That implies continuous efforts to reduce potentially toxic components in composite products, and finishes which are nontoxic, flame-proof, durable and easy to clean. Changes in fashion also require agility in supplying wood products in acceptable colours and surface textures: blond, clear and satinfinished today; perhaps red-brown, knotty and gloss-finished tomorrow.

Many developing countries installed small laboratories to test the basic pulp and paper properties of their national timber resources. Although these were quite useful in providing initial screening, a combination of advancing technology and economies of scale in commercial production have made it difftcult for the smaller laboratories to maintain a useful role. However, the skills acquired in these small laboratories might be put to good use if they were re-oriented towards development of new finished products and the exploration of new markets for non-wood forest products. Although many FRIs have devoted much effort to improving the range and productivity of fuelwoods, as well as charcoalmaking techniques and cooking stoves, generally they have focused more on the needs of the commercial sector. One of the major benefits from the sector reviews and studies undertaken as part of TFAP National Forestry Action programmes has been a broader, deeper and more quantitative appreciation of the needs for research to support non-commercial forest users.

Satisfaction of these needs for research may well require a range of expertise and facilities beyond those currently available at FRIs. Since, as we have outlined above, FRIs are often under the general government restrictions caused by structural adjustment programmes, they may be unable to expand to cope with the increased demand. Research consortia, involving FRIs, universities, NGOs and the private sector, can help to build multi-disciplinary teams to work on complex problems, especially those in which social factors play a large part.
Regional research co-operation

What happens when the necessary skills to address a problem are not available in a particular country? Is there provision for interchange of staff between neighbouring countries ? If problems are common to several countries which generally have common interests, the formation of regional consortia can be beneficial. A good model may be that of CORAF (Conference des responsables de (la) recherche agronomique africains, headquartered in Senegal). The member countries of CORAF do not have sufficient expertise to cover all their research needs for their staple crops but taken together they muster a large part of those needs. CORAF members collectively decide on the precise problems to be tackled and which institutes will take the lead for particular aspects of research. In this way, every member country of CORAF has a leading role in one or more aspects of research on a staple crop. It is thus motivated to maintain its leadership and to contribute to the research on other aspects which is led from neighbouring countries. CORAF research networks cover the main food crops in the francophone sub-Sahelian region, plus Madagascar. Anglophone countries are encouraged to join. There is also an agroforestry research' network planned by CORAF and consideration of a forestry association.

CORAF obviously has advantages in the similarities of ecosystems, culture, administrations and ethnicity among most of its member countries. These countries also belong to the regional treaty organization CILSS (Comité permanent inter-Etats de lutte contre la secheresse dans le Sahel, headquartered in Burkina Faso). CILSS helps to assure continuity of effort and political support for regional interactions.

The gradual development of regional forestry research under the CILSS umbrella could be instructive for other regions. Workshops to plan regional forestry research in Africa were organized by IUFRO's Special Programme for Developing Countries in Nairobi in 1986 and 1987. Technical approval for two of the proposed research networks was obtained from the forestry committee of SPAAR (Special Programme for African Agricultural Research, administered by the World Bank). The Government of France provided trust funds to FAO to run the first phase of a tree seed collection and distribution network (GCP/FRA/234/RAF) in the CILSS countries. Other bilateral donors (Germany and the Netherlands) provided additional support, perhaps because the research complemented their 
contributions to the TFAP exercises in the same sub-Sahelian countries.

The success of the tree seed network has rekindled interest in more comprehensive regional and continental collaboration. Based on the experience of FORSPA (Forestry Research Support Programme for Asia and the Pacific, headquartered in Thailand), IUFRO and FAO convened a joint meeting in Ouagadougou in October 1993 to detemine if there was interest in establishing a similar regional organization (a Forestry Research Support Programme for Africa). A follow-up meeting has been held recently at Nairobi, as part of the AAS-IFS international symposium on Supporting Capacity Building in Forestry Research in Africa (June-July 1994). An important background paper was prepared jointly for this meeting by Jeff Odera (Kenya) and Pape Sall (Senegal). It contains a proposal for an Africa-wide umbrella secretariat for forestry research, under which individual networks of diverse types might be created to focus on particular problems. This initiative would be almost the first for forty years, since the continental collaboration on vegetation classification in the late 1950s (the Yangambi meetings).

The development of regional and other research networks should be aided by recent compilations about the factors which collectively make a network a success (Plucknett, Smith \& Ozgediz 1990; FAO 1993). Compilations specific to forestry include Burley 1989; Gregersen, Lundgren \& Bengston 1990; Ng 1992.

\section{International agencies in forestry research}

It should not be necessary in a symposium organized by a IUFRO subject group to reiterate the important and catalytic role played by IUFRO and its research groups for over a century. However, IUFRO has had great difficulty in fostering research in developing countries. Political and institutional support which is recognized as a basic necessity for sustained successful research in industrialized countries may be weak or absent in developing countries. A major part of IUFRO's activities centres round technical meetings of the type in which we are now participating. However, travel funds are scarce and foreign currency to pay the registration fee and subsistence may be extremely hard to obtain in many developing countries. Donor agencies may be willing to provide support, if they are notified in sufficient time and if the developing country personnel play an important and active role in the organization and running of the meeting. Donors often insist that the supported person is significantly involved in a project supported by that donor.

IUFRO itself, as a voluntary association of scientists, does not dispose of funds for providing support for participation in tcclinical meetings or even its own World Congresses. The Special Programme for Developing Countries (SPDC), established with support from UNDP, US-AID and the Worlcl Bank in 1983, has struggled to raise funds for research planning meetings and training courses, and more recently for the preparation of training materials, particularly those of a distancelearning type. Neither IUFRO as the parent body nor the SPDC has been able to fund the operation of research networks. IUFRO's Executive Board decided some years ago that it did not wish to change its constitutional and legal structure so that it could operate as an executing agency, able to receive funds from donors and to implement research activities in conjunction with partners in national forestry research systems.

This decision was eminently rational from the point of view of IUFRO's governing body. IUFRO has been remarkably successful and costeffective in operating in a well-defined and highly collaborative mode. Adding a developmental responsibility to its functions would be a very major step and would have changed substantially the character of IUFRO.

Nevertheless, the decision left a gap in the efforts to contain deforestation and improve productivity of the remaining forests in developing countries. Sector surveys under TFAP coordination, together with World Bank environmental action plans and IUCN-supported national conservation strategies, revealed or emphasized numerous instances of problems requiring research which were common to major ecosystems and groups of countries. Research was initially confined to a rather minor role in TFAP. However, within two years the need was appreciated for research-based knowledge from which to develop new options for policies and practices. The first recommendation to be taken up after the 1987 Bellagio conference on TFAP was that for action on research (WRI 1987). The Rockefeller Foundation, together with UNDP, the World Bank and FAO, sponsored the International Task Force on Forestry Research (ITFFR) which reported at the 1988 Bellagio meeting (Holmes et al. 1988). The donors at the 1988 conference decided against the institutional options preferred 
by the ITFFR. However, the Consultative Group on International Agricultural Research (CGIAR) took up the challenge of providing institutional homes for international forestry and agroforestry research. The CGIAR absorbed the International Center for Research in Agroforestry (ICRAF) in 1991, after ICRAF had been a non-associated centre for some years, and began to create a new Center for International Forestry Research (CIFOR), also in 1991. CIFOR became operational in 1993.

\section{Center for International Forestry Research (CIFOR)}

CIFOR's primary role is to conduct research in areas where international externalities would render it inefficient for national research systems to be active. However, it is expected and intended that CIFOR 's research will be conducted in close partnership with national researchers and that an important by-product of our work will be the strengthening of national capacity to undertake research on forest systems. Many ingredients are required if capacity is to be strengthened.

It is important that the comparative advantages of different international agencies are recognized in attempts to provide these ingredients to the forest research community in developing countries. The purpose of this paper is to set out the strategy that CIFOR intends to adopt and also to comment on the potential role of other international agencies in contributing to capacity building. The basic premise of the paper is that performance in any enterprise will be enhanced if institutions maintain a narrow focus on areas where they have a comparative advantage. This applies both to the researchers and the research institutions in developing countries and to CIFOR itself. The basic rule which must govern our management activities is that we must constantly be seeking to focus on those things that we can do well and to leave to others those things for which they are better suited.

CIFOR is only one year old and itself disposes of relatively limited resources for strengthening research in developing countries. It isnccessary for us to be highly selective, both in our choice of partners and in the choice of research areas where we attempt to have an impact. Our contribution will have to focus on researc $h$ to produc e regional or global generalizations or new methodologies. We will also be contributing to improved communication between researchers in developing countries and to the ability of national forestry research systems to access and manage information CIFOR initiatives to develop new databases, and particularly to develop interfaces between existing databases, will hopefully be of value to researchers in the region.

At present, CIFOR has four main research foci for Africa:

a. Communitv management of drv woodlands. The potential for very major impacts by optimizing the balance between community resource management and government regulation in dry zone woodlands. by drawing upon research from both the social and bio-physical sciences is seen to be an area where CIFOR could have significant impact. We are, at present, developing a small consortium of social and forest sciences to produce a synthesis of these issues for th miombo region and to develop comparative studies between the situations in the different countries in which miombo and related woodlands occur.

b. Silvicultural management of natural forests. CIFOR will be collaborating with UNEP and with the scientist of CIRAD-Forêt in France to develop an overview of experiences of silviculture and management of forests in the moist semideciduous and wetter types of tropical forests in West and Central Africa. The UNEP project will focus on the Anglophone countries of West Africa, and we hope to work in partnership with research institutions in Ghana and Nigeria. The component funded through CIRAD-Forêt will focus on the Francophone countries of Central Africa. The overall objective is to produce a synthesi s of research o $\mathrm{n}$ incentive $\mathrm{s}$ and methodologies for sustainable management of near-natural closed broad-leaved forests for timber, non-wood products and environmental services.

c. The reforestation of degraded lands. Forest cover has been degraded over much of Africa. CIFOR will be conducting research on genotypesite matching which should have applications in many parts of Africa. This will be coupled with socio-economic research on the constraints to reforestation imposed by tree and land tenure systems, government economic policies, etc.

d. Integrated conservation and development Project. Understanding the behaviour of households in areas adjacent to reserves established for biodiversity conservation should contribute to improving the success of so-called 
"buffer zone" projects. These have generally yielded disappointing results up until now because they have based their approach far too much on advocacy and not enough on an appreciation of the response of households to opportunities provided by local markets, regulations, etc.

\section{Comparative roles of other international agencies}

Of course, CIFOR and IUFRO are not alone in promoting and strengthening forestry research in developing countries. The principal international agencies who might be expected to have an impact on forest research in Africa in the coming decade are the multilateral development banks (the World Bank and the African Development Bank), and the UN specialized agencies (particularly FAO and UNESCO). Development assistance channelled through bilateral agencies will continue to have important functions. The respective roles of these agencies in Africa might include the following:

The World Bank and the African Development Bank. The major impact of these institutions, together with the International Monetary Fund, is likely to be through their promotion of structural adjustment in the public sector in most African countries. It is going to be essential that the forest research community can plead its case with these agencies and their government counterparts in finance ministries in order to secure the basic core funding to maintain the integrity of forest research institutes. The World Bank is certainly sensitive to the issues involved, and the experience of the recent structural adjustment loans to Ghana and their impact on re-designing the forest research capacity in the country is instructive. Both the African Development Bank and the World Bank are likely to be the major dispersers of funds for global environmental externalities and thus important sponsors of forest research. The primary focus of their demand wilt bc carbon sequestration and the impact of different land use management strategies on carbon storage and biodiversity. Social science research to underpin the devolution of management responsibility to households local communities and the private sector is likely to be an area of growth in funding from these agencies.

The UN specialized agencies. FAO will be the principal international agency facilitating communication between technical bodies involved with forest management and research in Africa. FAO is seeking to develop a forest research network for Africa. This is likely to provide new opportunities for collaboration between different types of institute with a capacity to conduct research on forests. UNESCO has an important role in strengthening capacity of education and training institutions in support of forest research.

Bilatera 1de velopmen $\mathrm{t}$ assistance agencies, The bilateral agencies are likely to remain the major source of technical assistance to strengthen the rcscarch capacity of institutes in Africa. Their special advantage lies in their ability to draw upon resources from their own national research systems, many of which have a long history of involvement in Africa. The effective collaboration available through British ODA, the Dutch DGIS and the Tropenbos programme, German BMZ and GTZ and their university faculties, and the French FAC and CIRAD-Forét, are amongst the most important potential partners for forest researchers in Africa over the coming decade. External funds required to improve the physical facilities and operating conditions of forest researchers in the public sector will continue to come primarily from these sources, together with Japanese JICA. The trend for the multilateral agencies to contribute major capital components of forest research programmes in collaboration with the bilateral agencies is likely to be maintained.

\section{Conclusion}

Management of any enterprise must respond constantly to a changing external environment. The assessment of the situation, problems and opportunities confronting forest research in Africa that we have presented in this paper is based on a rather distant view of the continent from our headquarters in Bogor, and on a number of studies that have been specifically commissioned on African research issues (including Burley et al. 1989; Burley \& Cossalter 1988; Carlson \& Shea 1986; Cossaltcr 1987; lyamabo et al.1988; lyamabo \& El-Lakany 1988; Odera \& Salt 1994; SADC 1992; Sales 1987; Salmi 1992; Sayer \& Palmer 1994; Wencelius 1985; World Bank 1987). We see that meetings, such as the one in which we are participating, are essential if we are to be sufficiently sensitive to the needs and perceptions in the African research institutes in order that our own activities produce the maximum benefits, both in terms of research output and capacity enhancement. We wish to intensify this dialogue, but to do so primarily through sharply-focused research initiatives that will address critical issues for forest conservation and management in Africa 
and will bring together consortia of diverse partners. The diversity will come both from mobilizing the resources of different disciplines and from different countries. We hope that we can contribute to establishing a research agenda which will be attractive to the multilateral and bilateral funding agencies, and that we can also optimize our relationships with FAO and IUFRO so that the multiplier effects provided by their networks can also be optimized. We see this meeting as a major opportunity for initiating new partnerships and new research activities on this continent and hope that it will serve to bring us one step nearer to our colleagues in the region. Our overall objective must be to make the forests of Africa more valuable to all their users, but especially to ensure that this value accrues equitably to all the users and particularly the poorer sectors of society who live in closest contact with the forests.

\section{References}

Burley, J., 1989, 'Options for forestry research networking .' In Lundgren, A.L. (Editor) The management of large-scale forestry research programs and projects. Proceedings of a meeting of IUFRO Subject Group S6.06 Management of forestry research, April 17-19, 1989, Alice Holt Lodge, Farnham, England. General Technical Report number NE- 130. Broomall, Pennsylvania; U.S. Forest Service Northeastern Forest Experiment Station. p185-199.

Burley, J., and seven other authors, 1989, 'Forestry research in Eastern and Southern Africa: based on a contribution to the World Bank's Sub-Saharan Africa Agricultural Research Review, 1986 Tropical Forestry Paper number 19. Oxford, U.K.; Oxford Forestry Institute. 58p + 27 annexes separately paginated.

Burley, J. and Cossalter, C.G. ,1988, Report on tree improvement. Background paper for the IUFRO regional planning workshop for East and Southern Africa, Lilongwe, Mala-i, 19-28 October 1988. Vienna, Austria; International Union of Forestry Research Organizations, Special Programme for Developing Countries. $42 p+8$ annexes separately paginated.

Carlson, L.W. and SHEA, K.R. (compilers), 1986, Increasing productivity of multipurpose lands. Proceedings of the IUFRO research planning workshop for Africa (Sahelian and North Sudanian zones), Nairobi, Kenya, 9-15 January 1986. Hull, Canada; Canadian Forest Service. 333p.

Cossalter, C.G. , 1987, Overview of current forestry research situation and future trends in Africa south of the Sahara. SPAAR meeting, Paris, France, 9-10 September 1987. Rome, Italy; Food and Agriculture Organization of the United Nations, Forestry Department.

Gregersen, H.M., Lundgren, A.L., and Bengston, D.N., 1990, Planning and managing forestry research: guidelines for managers. FAO Forestry Paper 96. Rome, Italy; Food and Agriculture Organization of the United Nations. I81 p.

Holmes, G.D. and twelve other authors, 1988, A global research strategy for tropical forestry. Report of an international task force on forestry research. New York; The Rockefeller Foundation, the United Nations Development Programme, the World Bank and the Food and Agriculture Organization of the United Nations. 88p.

FAO, 1993, Guidelines for the establishment and suppport of technical cooperation networks. Rome, Italy; Evaluation Service, Food and Agriculture Organization of the United Nations. In: Proceedings of the meeting of experts on forestry research. Rome, 12-14 October 1992. FAO Forestry Paper 110. Rome, Italy; Food and Agriculture Organization of the United Nations. p244-258. [see also KATO 19921.

Iyamabo, D.E. (Editor)., Cossalter, C., Iyamabo, D.E., Krugman, S.L. and Fugalli, O. (compilers) (undated, but 1988) Tree improvement and silvo-pastoral management in Sahelian and North Sudanian Africa: problems, needs and research proposals. Vienna, Austria; International Union of Forestry Research Organizations, Special Programme for Developing Countries. 196p.

Iyamabo, D.E. and El-Lakany, M.H., 1988, Forestry research in Afiica: problems, priorities and needs. Background paper number 3. International Task Force on Forestry Research. New York; The Rockefeller Foundation. 35p + 16p annex. 
Kato, M., 1992, Research support networks: review of FAO experience with research networks. Paper number 16, expert meeting on forestry research. Rome, 12-14 October 1992. Rome, Italy; Food and Agriculture Organization of the United Nations, Forestry Department. $13+3 \mathrm{p}$.

Odera, J. and Sall, P., 1994, Forestry research network for Sub-Saharan Africa (FORNESSA). A concept/discussion paper presented at a meeting of the AAS-IFS international symposium (in collaboration with FAO) on Supporting Capacity Building in Forestry Research in Africa. Nairobi, Kenya, 28 June-1 July 1994. 29p.

Ng, F.S.P., 1992, Research management in forestry. FAO Forestry Paper no. 102. Rome, Italy; Food and Agriculture Organization of the United Nations. ISBN 92-5-103202-5. I20p.

Plucknctt, D.L., Smith, N.J.H., and Ozgcdiz, S., 1990, networking in international Agricultural research. Ithaca, New York; Cornell University Press. 1SBN 0-8014-2384-8. 2241p

SADC, 1992, Forestry research plan for the SADC region. SADC project AAA.5.23 improvement and strengthening of forestry and forest products research institutions in the SADC region. Lilongwe, Mala_i; SADC Forestry Sector Technical Coordination Unit. 126p.

Sales, C., 1987, Enquête sur les besoins de recherche en technologie du bois pour le continent africain; (projet). Paris, France; Centre Technique Forestier Tropical, IUFRO Project Group P5.01 Properties and utilization of tropical woods. 28p.

Salmi, J., 1992, Research support networks: research support for the SADCC region. Paper number 20, expert meeting on forestry research. Rome, 12- 14 October 1992. Rome, Italy; Food and Agriculture Organization of the United Nations, Forestry Department.12 + 10p.

Sayer, J.A. and Palmer, J.R., 1994, .Overview of forest research in Africa. Invited paper presented at a meeting of the AAS-IFS international symposium (in collaboration with FAO) on Supporting Capacity Building in Forestry Research in Africa. Nairobi, Kenya, 28 June-1 July 1994. 25p.

Wencelius, F., 1985, Forestry research in the Sahel countries. Centre national du machinisme agricole, du génie rural, des eaux et des forêts, France. Washington, D.C.; World Bank. 91p.

WORLD BANK., 1987, West Africa Agricultural Research Review, 1985-86. Washington, D.C.; World Bank West Africa Projects Department. 413p.

WRI (WORLD RESOURCES INSTITUTE), 1987, Statements and background documents from the Bellagio Strategy Meeting on Tropical Forests. Washington, D.C.; World Resources Institute. 


\title{
Acronyms
}

\author{
AAS African Academy of Sciences, Kenya \\ BMZ Bundesministerium für Wirtschaftliche Zusammenarbeit, Federal Republic of Germany \\ CGIAR Consultative Group on International Agricultural Research, USA \\ CIFOR Center for International Forestry Research (CGIAR), Indonesia \\ CILSS Comité permanent inter-États de lutte contre la sécheresse dans le Sahel, Burkina Faso \\ CIRAD Centre de coopération internationale en recherche agronomique pour le développement, France \\ CIRAD-Forêt formerly Centre Technique Forestier Tropical (CTFT), France \\ CORAF Conférence des responsables de (la) recherche agronomique africains, Sénégal \\ CSIR Council for Scientific and Industrial Research, South Africa \\ DGIS Directorate-General for International Cooperation, Netherlands \\ FAO Food and Agriculture Organization of the United Nations, Italy \\ FORSPA Forestry Research Support Programme for Asia and the Pacific, Thailand \\ GTZ Deutsche Gesellschaft für Technische Zusammenarbeit, Federal Republic of Germany \\ ICRAF International Centre for Research in Agroforestry (CGIAR), Kenya \\ IFS International Foundation for Science, Sweden \\ ITFFR International Task Force on Forestry Research (convened by the Rockefeller Foundation, the \\ United Nations Development Programme, the World Bank and the Food and \\ Agriculture Organization of the United Nations for the Bellagio II meeting in \\ November 1988 on tropical forestry research, Wiston House, Wilton Park, UK) \\ IUCN International Union for Conservation of Nature and Natural Resources, the World \\ Conservation Union, Switzerland \\ IUFRO International Union of Forestry Research Organizations, Austria \\ JICA Japan International Cooperation Agency, Japan \\ NARS National Agricultural Research Service/System/Systems \\ NFRS National Forestry Research Service \\ NGO non-governmental organization \\ ODA Overseas Development Administration, UK \\ SPAAR Special Programme for African Agricultural Research (World Bank), USA \\ SPDC Special Programme for Developing Countries (IUFRO), Austria \\ TFAP Tropical Forestry Action Programme (coordinated by FAO) \\ UNDP United Nations Development Programme, USA \\ UNEP United Nations Environment Programme, Kenya \\ UNESCO United Nations Educational, Scientific and Cultural Organization, France \\ US-AID United States Agency for International Development, USA
}

